\title{
GAMBARAN PENGETAHUAN DAN SIKAP WUS DALAM UPAYA PENCEGAHAN KANKER SERVIKS MELALUI TES IVA DI PUSKESMAS PUTRI AYU
}

\author{
Nurfitriani \\ Dosen D3 Keperawatan STIKes Baiturrahim Jambi \\ Email :nurfitriani_1173@yahoo.com
}

\begin{abstract}
In Indonesia Cervical cancer is Cancer with the highest prevalence of about $0.8 \%$ or about 98,692 patients.Data from the health department Jambi city indicated that the women of childbearing age that positive cervical cancer on examination IVA at the public health center Putri Ayu Jambi city. This study aimed to determine the correlation of knowledge and attitude of women of childbearing age with cervical cancer prevention efforts. This is a quantitative research by using Cross Sectional design. This study was conducted on Aprils/d August 2018 with samples were 45 respondents, it used questionnaire, analyzed as univariate.The findings indicated that, 24 respondents $(53,3 \%)$ have hightprevention efforts, 27 respondents (60\%) have hight knowledge, and than 21 respondents $(46,7 \%)$ have positive attitude.The higer the knowledge the better the prevention efforts, the attitude of a person does not affect the influence of prevention efforts, prevention efforts do not affect the attitude. It is expected that the public health center can provide information to childbearing age about prevention cervical cancer by health promotion or counseling and giving motivation to women of childbearing age to do the examination IVA or pap smear.
\end{abstract}

Keywords : Knowledge, attitude, cervical cancer prevention

\begin{abstract}
ABSTRAK
Indonesia merupakan penyakit kanker dengan prevalensi tertinggi yaitu sekitar 0,8\% atau sekitar 98.692 penderita. Penelitian ini merupakan penelitian kuantitatif dengan desain cross sectional, dengan pengambilan sampel menggunakan teknik Purposive Sampling yaitu WUS yang berkunjung ke poli KB dan Imunisasi di Puskesmas Putri Ayu Kota Jambi. Sampel diambil sebanyak 20\% dari jumlah populasi yaitu 45 responden. Penelitian ini dilakukan di Puskesmas Putri Ayu Kota Jambi yang dilaksanakan selama 7 bulan. Variabel yang diuji menggunakan variabel dependent yaitu upaya pencegahn kanker serviks dan Variabel independent yaitu pengetahuan dan sikap. Analisis yang digunakan adalah univariat . Hasil penelitian diperoleh Lebih dari setengah responden 24 responden $(53,3 \%)$ memiliki upaya pencegahan baik., Sebagian besar responden 27 responden (60\%) memiliki pengetahuan tinggi dan 21 responden (46,7\%) memiliki sikap positif.
\end{abstract}

Kata kunci: Pengetahun, Sikap, Pencegahan CA Serviks 


\section{PENDAHULUAN}

Kanker merupakan masalah kesehatan utama bagi masyarakat di seluruh dunia, salah satunya adalah kanker serviks. Menurut data dari organisasi kesehatan dunia (World Health Organization atau WHO), setiap tahunnya ada sekitar 6,25 juta jiwa terkena kanker dan 9 juta jiwa meninggal dunia dalam 80 tahun terakhir. Secara nasional prevalensi penyakit kanker pada penduduk Indonesia tahun 2013 sebanyak 14\% atau diperkirakan sekitar 347.792 orang, dimana terdapat 2 kanker menempati urutan tertinggi yaitu kanker serviks dan kanker payudara ( Pusat data dan informasi Kemenkes RI, 2015). kanker serviks merupakan penyebab kematian nomor dua di dunia pada kaum hawa dari seluruh penyakit kanker yang ada.

Kanker leher rahim (kanker serviks) adalah tumor ganas yang tumbuh di dalam leher rahim/serviks (bagian terendah dari rahim yang menempel pada puncak vagina (Nugroho dan Utama, 2014).Serangan kanker ini pada tahap awal tidak menimbulkan gejala apapun. Itulah sebabnya, mengapa kanker jenis ini masuk dalam kategori silent killer (Tilong, 2014). Kanker leher rahim atau disebut juga kanker serviks adalah sejenis kanker yang 99,7\% disebabkan oleh human papilloma virus (HPV) onkogenik, yang menyerang leher rahim. Di Indonesia hanya 5\% yang melakukan penapisan kanker leher rahim, sehingga $76,6 \%$ pasien ketika terdeteksi sudah memasuki stadium lanjut (IIIB ke atas), karena kanker leher rahim biasanya tanpa gejala apapun pada stadium awalnya.

Insiden kejadian kanker serviks di Indoneisa adalah $<19,92 \%$ per 100.000 wanita per tahun. Di Indonesia setiap harinya terdapat 41 kasus baru kanker serviks dan 20 wanita meninggal dunia sehingga diperkirakan setiap satu jam seorang perempuan meninggal karena kanker serviks (Yuliatin, 2010). Menurut Kementerian Kesehatan Republik Indonesia melalui riset kesehatan dasar (2013) menyatakan bahwa penyakit kanker serviks di Indonesia merupakan penyakit kanker dengan prevalensi tertinggi yaitu sekitar 0,8 $\%$ atau sekitar 98.692 penderita. Berdasarkan estimasi jumlah penderita kanker serviks terbanyak terdapat pada provinsi Jawa Timur atau berjumlah 21.313, kemudian Jawa Tengah berjumlah 19.743 dan Jawa Barat berjumlah 15.635. Sedangkan Provinsi Jambi masuk dalam 10 besar penderita kanker serviks dengan jumlah 1.792 penderita (Buletin Jendela data dan Informasi Kesehatan , 2015).

Menurut para ahli kanker, kanker serviks merupakan salah satu jenis kanker yang paling bisa dicegah dan bisa diobati. Faktor resiko terjadinya kanker meliputi : faktor genetic, faktor infeksi, faktor gaya hidup, dan faktor aktivitas fisik. Oleh karena itu, skrining lesi pra kanker sangat penting sekali karena pengobatannya bisa menyembuhkan sampai $100 \%$. Sedangkan pada kanker invasif, penggunaan lesi memberikan hasil yang kurang memuaskan dengan harapan hidup 5 tahun, yaitu antara 20\%-90\% (Subagja, 2014).

Salah satu penyelenggaraan 
skrining kanker serviks adalah metode Inspeksi Visual dengan Asam Asetat (IVA) yang memiliki keakuratan 90\% (Rahma dan Prabandari, 2011). IVA adalah sebuah metode yang mudah untuk dipelajari, murah dan membutuhkan peralatan minimal daripada prasarana laboratorium dan memberikan hasil yang sebentar, sehingga akurat untuk mendiagnosa (Denny and Rengaswamy,2006).

Syarat dalam melakukan pemeriksaan tes IVA antaranya WUS sudah aktif secara seksual, tidak sedang hamil atau datang bulan, dan dalam waktu 24 jam sebelumnya tidak melakukan hubungan intim. Tes IVA ini juga tidak dianjurkan bagi wanita menopause. Hasil dari pemeriksaan IVA jika dinyatakan positif, anjurannya dilakukan tes IVA setiap tahun, namun jika hasil negatif dapat dilakukan setiap 5 tahun.

Kesadaran wanita Indonesia untuk melakukan detksi dini kanker serviks secara teratur masih cukup rendah berkisar 5\% sehingga wanita yang mengalami kanker serviks di temukan sudah masuk dalam stadium lanjut dan sering sudah tidak dapat diatasi lagi (Rahma dan Prabandari, 2011). Faktor -faktor yang menyebabkan wanita enggan memeriksakan dirinya untuk melakukan deteksi dini dikarenakan rasa takut, tidak nyaman, segan, malu dan terkadang ada yang dilarang oleh suaminya. WUS juga terkadang khawatir dengan hasil pemeriksaan dan lbih memilih untuk menghindarinya.

Pengetahuan ibu tentang kanker serviks akan membentuk sikap positif terhadap rendahnya deteksi dini kanker serviks. Hal ini juga merupakan faktor dominan dalam pemeriksaan deteksi dini kanker serviks. Pengetahuan dan pendidikan yang dimiliki wanita usia subur tersebut akan menimbulkan kepercayaan ibu tentang deteksi dini kanker serviks (Martini, 2013). Cakupan dektesi dini kanker serviks di Indonesia masih sangat rendah yang hanya berkisar 5\%. Hal ini disebabkan oleh kurangnya pengetahuan tentang kanker serviks sehingga angka kejadian kanker serviks meningkat setiap tahunnya.. Sosialisasi mengenai pencegahan kanker serviks sangat diperlukan untuk dapat mengubah perilaku wanita dalam menjaga kesehatan organ reproduksinya, karena kanker serviks merupakan jenis kanker yang paling dapat dicegah yaitu dengan menghindari faktor resiko seperti pemilihan pembalut, penggunaan spray vagina, aktivitas seksual yang terlalu dini, hubungan seksual dengan banyak pasangan, menghindari pajanan terhadap penyakit menular seksual, melakukan skrining atau deteksi dini, dan vaksinasi HPV. Diet rendah vitamin $\mathrm{A}$, vitamin $\mathrm{C}$, beta karoten, asam folat dapat menjadi faktor pencetus kanker serviks. Deteksi dini kanker serviks dapat dilakukan dengan metode IVA (Inspeksi Visual dengan Asam Asetat) atau pemeriksaan pap smear (Arum, 2015). Pengetahuan yang baik diharapkan dapat memunculkan kesadaran untuk dapat melakukan pemeriksaan dini kanker serviks.

Berdasarkan survey awal yang dilakukan pada tanggal 8 dan 10 April 2018 kepada 10 wanita usia subur (WUS) yang berada di 
Puskesmas Putri Ayu, menggunakan beberapa pertanyaan mengenai pengetahuan wanita usia subur tentang kanker serviks, sikap terhadap kanker serviks dan upaya pencegahan kanker serviks. Dari 10 WUS yang diwawancara sebanyak 4 WUS mengetahui tentang kanker serviks dan upaya pencegahannya. 4 WUS mengetahui pengertian kanker serviks, 3 WUS mengetahui gejala kanker serviks, 2 WUS mengetahui faktor resiko kanker serviks dan hanya 1 WUS mengetahui penyebab, gejala yang timbul pada stadium lanjut dan jumlah stadium pada kanker serviks . Keempat WUS mengatakan tidak setuju apabila semua wanita memiliki peluang besar terkena kanker serviks, 4 WUS mengatakan apabila menerapkan hidup sehat akan terhindar dari kanker serviks sehingga belum ada keinginan untuk melakukan tes IVA. Sedangkan 6 WUS lainnya tidak mengetahui sama sekali tentang kanker serviks dan upaya pencegahannya.

Tujuan dari penelitian ini untuk mengetahui Gambaran pengetahuan dan sikap wanita usia subur (WUS) dalam upaya pencegahan kanker serviks melalui tes IVA. Hasil peneltian ini dapat digunakan untuk menambah informasi dan wawasan ilmu pengetahuan kesehatan terutama bagi WUS melalui promosi atau penyuluhan kesehatan.

\section{METODE PENELITIAN}

Penelitian ini merupakan penelitian kuantitatif dengan desain cross sectional, dengan pengambilan sampel menggunakan teknik Purposive Sampling yaitu WUS yang berkunjung ke poli KB dan Imunisasi di Puskesmas Putri Ayu Kota Jambi. Sampel diambil sebanyak 20\% dari jumlah populasi (Arikunto,2006) yaitu 45 responden,Penelitian ini dilakukan di Puskesmas Putri Ayu Kota Jambi yang dilaksanakan selama 7 bulan Variabel yang diuji menggunakan variabel dependent yaitu upaya pencegahn kanker serviks dan Variabel independent pada penelitian ini adalah pengetahuan dan sikap. Analisis yang digunakan adalah univariat .

\section{HASIL DAN PEMBAHASAN}

\section{Analisa Univariat}

Hasil analisis univariat bertujuan untuk mengetahui distribusi frekuensi variabel yang diteliti, yaitu : Pengetahuan dan sikap dengan upaya pencegahan kanker serviks melalui tes IVA.

\section{a. Upaya Pencegahan Kanker Serviks}

Untuk melihat gambaran upaya pencegahan kanker serviks di Puskesmas Putri Ayu Kota Jambi tahun 2018, maka ada beberapa item dari konsep pencegahan kanker serviks yang akan dibahas seperti menghindari faktor resiko, menerapkan pola hidup sehat, pemberian vaksinasi dan melakukan deteksi dini melalui tes IVA. Untuk mengetahui secara rinci item yang dibahas dan hasil secara keseluruhan jawaban responden dapat dilihat pada tabel 5.6 berikut :

\section{Tabel 1. Distribusi Frekuensi WUS Berdasarkan Item Pernyataan Upaya Pencegahan}


Kanker Serviks di Puskesmas Putri Ayu Kota Jambi Tahun 2018 vagina yang mengandung antiseptik dengan kosentrasi tinggi dapat mencegah kanker serviks. Namun masih banyak WUS $26 \quad(57,8 \%)$

\begin{tabular}{|c|c|c|c|c|c|}
\hline \multirow{3}{*}{ No } & \multirow{3}{*}{ Pernyataan } & \multicolumn{4}{|c|}{ Distribusi Frekuensi } \\
\hline & & \multicolumn{2}{|c|}{ Ya } & \multicolumn{2}{|c|}{ Tidak } \\
\hline & & $\mathbf{F}$ & $\%$ & $\mathbf{F}$ & $\%$ \\
\hline 1 & $\begin{array}{l}\text { Tidak berganti-ganti pasangan dapat terhindar } \\
\text { dari kanker serviks }\end{array}$ & 22 & 48.9 & 23 & 51,1 \\
\hline 2 & $\begin{array}{l}\text { Berhati-hati dalam memilih pembalut } \\
\text { merupakan cara menghindari faktor resiko } \\
\text { terkena kanker serviks }\end{array}$ & 26 & 57,8 & 19 & 42,2 \\
\hline 3 & $\begin{array}{l}\text { Selalu menjaga kebersihan organ intim dapat } \\
\text { terhindar dari keputihan }\end{array}$ & 16 & 35,6 & 29 & 64,4 \\
\hline 4 & $\begin{array}{l}\text { Penggunaan pembersih vagina yang } \\
\text { mengandung antiseptik dengan konsentrasi } \\
\text { tinggi dapat mencegah kanker serviks }\end{array}$ & 28 & 62,2 & 17 & 37,8 \\
\hline 5 & $\begin{array}{l}\text { Kebersihan dan kekeringan organ intim } \\
\text { terutama saat haid dapat mencegah } \\
\text { terserangnya kanker serviks }\end{array}$ & 19 & 42,2 & 26 & 57,8 \\
\hline 6 & $\begin{array}{l}\text { Agar terhindar dari kanker serviks sebaiknya } \\
\text { menikah di usia muda }\end{array}$ & 23 & 51,1 & 22 & 48,9 \\
\hline 7 & $\begin{array}{l}\text { Wanita yang senang mengkonsumsi makanan } \\
\text { berlemak dan makanan instan/ mengandung } \\
\text { pengawet berisiko terkena kanker serviks }\end{array}$ & 24 & 53,3 & 21 & 46,7 \\
\hline 8 & $\begin{array}{l}\text { Perokok merupakan salah satu penyebab } \\
\text { timbulnya kanker serviks }\end{array}$ & 27 & 60 & 18 & 40 \\
\hline 9 & $\begin{array}{l}\text { Vaksinasi HPV berguna mencegah kanker } \\
\text { serviks }\end{array}$ & 20 & 44,4 & 25 & 55,6 \\
\hline 10 & $\begin{array}{l}\text { Imunisasi HPV hanya boleh diberikan kepada } \\
\text { WUS yang telah aktif secara seksual }\end{array}$ & 26 & 57,8 & 19 & 42,2 \\
\hline 11 & $\begin{array}{l}\text { Wanita yang sudah aktif secara seksual } \\
\text { dianjurkan melakukan tes IVa }\end{array}$ & 21 & 46,7 & 24 & 53,3 \\
\hline 12 & $\begin{array}{l}\text { Wanita usia subur dianjurkan melakukan } \\
\text { vaksinasi sebanyak 3x dalam waktu } 6 \text { bulan` }\end{array}$ & 20 & 44,4 & 25 & 55,6 \\
\hline 13 & $\begin{array}{l}\text { Tes iVA merupakan salah satu deteksi dini } \\
\text { kanker serviks }\end{array}$ & 18 & 40 & 27 & 60 \\
\hline & $\begin{array}{l}\text { Berdasarkan tabel 1. diatas } \\
\text { nunjukkan bahwa } 26 \text { WUS } \\
\text {,8\%) mengetahui bahwa berhati } \\
\text { i dalam memilih pembalut } \\
\text { rupakan cara menghindari faktor } \\
\text { ko terkena kanker serviks, } \\
\text { nudian } 28 \text { WUS }(62,2 \%) \text { ibu } \\
\text { njawab penggunaan pembersih }\end{array}$ & $\begin{array}{l}\text { menja } \\
\text { an } \\
\text { terutan } \\
\text { ah } \\
\text { begi } \\
7\left(60{ }^{2}\right. \\
\text { per } \\
\text { kan } \\
\text { ervik }\end{array}$ & $\begin{array}{l}\text { lab } \\
\text { n kek } \\
\text { a saa } \\
\text { tersera } \\
\text { juga } \\
\text { ibu } 1 \\
\text { yataan } \\
\text { ah sa }\end{array}$ & $\begin{array}{l}\text { lah } \\
\text { ingan } \\
\text { haid } \\
\text { snya } \\
\text { nasih } \\
\text { njaw: } \\
\text { Tes } \\
\text { detel }\end{array}$ & $\begin{array}{r}\text { tentang } \\
\text { organ } \\
\text { dapat } \\
\text { kanker } \\
\text { banyak } \\
\text { b salah } \\
\text { IVA } \\
\text { si dini }\end{array}$ \\
\hline
\end{tabular}


Upaya pencegahan kanker serviks dibagi menjadi 2 kategori yaitu kurang baik dan baik. Untuk lebih jelasnya dapat dilihat berdasarkan tabel 5.7 dibawah ini :

Tabel 2. Distribusi Frekuensi WUS Berdasarkan Upaya Pencegahan Kanker Serviks di Puskesmas Putri Ayu Kota Jambi Tahun 2018

Tabel 2 Dstribusi Frekuensi Responden Berdasarkan Upaya Pencegahan Kanker Serviks

\begin{tabular}{crccc}
\hline & $\begin{array}{r}\text { Upaya } \\
\text { No }\end{array}$ & Jumlah & $\%$ \\
\hline \multirow{2}{*}{1} & Kuncegahan & & \\
\multirow{2}{*}{2} & Baik & 21 & 2 & 46,7 \\
& & 24 & 2 & 53,3 \\
\hline & Jumlah & 5 & 100 \\
\hline
\end{tabular}

Hasil penelitian pada tabel 2 terhadap 45 WUS didapatkan data bahwa, upaya pencegahan Kanker Serviks di Puskesmas Putri Ayu Kota Jambi Tahun 2018 termasuk dalam upaya pencegahan baik yaitu sebanyak 24 WUS $(53,3 \%)$.

Pencegahan baik dapat disebabkan pengetahuan WUS tentang kanker serviks sudah banyak yang tahu dan paham, begitu juga pendidikan WUS yang rata rata berpendidikan SMA/SMK juga merupakan domain terpenting terbentuknya suatu perilaku. Praktek atau tindakan akan terjadi setelah seseorang mengetahui stimulus atau objek kesehatan, kemudian mengadakan penilaian atau pendapat terhadap apa yang diketahui, proses selanjutnya diharapkan WUS melaksanakan pemeriksaan IVA (Notoatmodjo,2012).

Penelitian ini sejalan dengan penelitian Titik (2015) bahwa wanita usia subur yang memiliki upaya pencegahan kanker serviks kurang yaitu sebesar 48 orang (39\%), yang memiliki upaya pencegahan baik sebesar 24 orang $(53,3 \%)$, yang memiliki upaya pencegahan baik sekali sebesar 23 orang (19\%), dan yang memiliki upaya pencegahan istimewa sebesar 16 orang (13\%). Dapat disimpulkan bahwa secara umum upaya pencegahan kanker serviks pada wanita usia subur di Desa Ngino sebagian besar adalah kurang baik.

Penelitian ini tidak sejalan dengan hasil penelitian yang dilakukan oleh Azmanaili (2014) tentang Hubungan antara FaktorFaktor yang Mempengaruhi dengan Masalah Upaya Pencegahan Kankers Serviks di Puskesmas Perawatan Jakarta Timur Tahun 2014 didapatkan bahwa sebagian besar responden $45 \quad(80,3 \%)$ memiliki faktor upaya pencegahan kanker serviks kurang baik pada wanita usia subur. Hal ini perlu adanya peningkatan masalah upaya pencegahan kankers serviks yang baik terhadap masalah pasien dengan upaya pencegahan kanker serviks ke pelayanan kesehatan terdekat yang ada pada kondisi yang dialaminya sekarang untuk mencegah dari berbagai masalah kesehatan yang dialami oleh WUS saat adanya keluhan yang memperberat kondisi ibu pada saat sekarang.

Dari hasil penelitian di atas dapat dilihat bahwa total dari upaya pencegahan kanker serviks yang terbanyak adalah deteksi dini kanker 
serviks dapat dilakukan dengan pemeriksaan IVA sebanyak 34 responden $(64.0 \%)$. Hal ini perlunya pemberian informasi kesehatan yang baik terhadap pencegahan masalah kanker serviks dengan melakukan pemeriksaan ke pelayanan kesehatan terdekat dimana tujuanya menurunkan angka kejadian masalah kanker serviks yang terjadi pada wanita usia subur. Hasil penelitian ini sesuai dengan penelitian yang telah dilakukan oleh Wulandari (2012) yang menyatakan bahwa ada hubungan lingkungan dan dukungan keluarga tentang upaya pencegahan kankers serviks. Dengan nilai $p$ value $=0.003 \quad(p$-value $<0.05)$. Kondisi untuk mengatasi upaya pencegahan kanker serviks merupakan faktor risiko yang cukup signifikan hal ini dapat dilihat dari penelitian diatas, dengan masalah terjadinya kanker serviks pada wanita usia subur merupakan salah satu faktor yang dapat membunuh wanita usia subur, sehingga jika upaya pencegahan kanker serviks bagus maka masalah terjadinya kanker serviks bisa dicegah.

Kurang baiknya upaya pencegahan kanker serviks pada WUS di Puskesmas Putri Ayu Jambi ini masih ada sekitar $(46,7 \%)$ kemungkinan dikarenakan kurangnya kesadaran WUS untuk melakukan tindakan upaya pencegahan kanker serviks terutama tentang pencegahan primer. Pencegahan primer dapat dilakukan kepada indiidu atau populasi secara keseluruhan dengan cara membentuk kader-kader bina keluarga sehat untuk melakukan penyuluhan secara intensif melalui kegiatan ibu-ibu seperti pengajian, arisan RT mingguan atau bulanan dengan harapan ibu-ibu dapat termotivasi untuk melakukan imunisasi HPV dan pemeriksaan IVA di pusat pelayanan kesehatan terdekat seperti Rumah Sakit, Klinik ataupun Puskesmas.

b. Pengetahuan tentang Upaya Pencegahan Kanker Serviks

Untuk melihat gambaran pengetahuan tentang Upaya Pencegahan Kanker Serviks di Puskesmas Putri Ayu Kota Jambi Tahun 2018, maka ada beberapa item dari konsep kanker serviks yang akan dibahas seperti pengertian, penyebab, faktor resiko, dan upaya pencegahan. Untuk mengetahui secara rinci item yang dibahas dan hasil secara keseluruhan jawaban responden dapat dilihat diketahui beriku init :

Berdasarkan tabel 2 di atas distribusi jawaban WUS Berdasarkan item Pernyataan Pengetahuan dengan Upaya Pencegahan Kanker Serviks di Puskesmas Putri Ayu Kota Jambi Tahun 2018, menunjukkan bahwa banyak WUS yang mengetahui penyebab kanker serviks 26 responden $(57,82 \%)$ menjawab benar. Kemudian responden juga banyak yang mengetahui tentang tujuan pemberian imunisasi HPV pada wanita sebanyak 32 orang (71\%) menjawab salah, dan sebanyak 32 WUS $(71 \%)$ menjawab benar tentang syarat untuk melakukan tes IVA. Sedangkan untuk pernyataan apa yang dimaksud dengan kanker hanya 22 WUS $(48,9 \%)$ menjawab benar, itu berarti masih banyak responden yang belum mengetahui pengertian kanker serviks. Kemudian masih banyak juga responden tidak mengetahui yang termasuk cara menghindari faktor resiko terhindar dari kanker 
serviks karena hanya 22 responden $(48, \%)$ responden menjawab benar. Dan hanya 15 responden (30\%) responden menjawab benar tentang tujuan dari pemeriksaan IVA. Padahal pemeriksaan IVA merupakan deteksi dini kanker serviks yang wajib dilakukan satu tahun sekali. Berdasarkan hasil distribusi frekuensi pengetahuan dengan upaya pencegahan kanker serviks dibagi menjadi 2 kategori yaitu rendah dan tinggi. Untuk lebih jelasnya dapat dilihat berdasarkan tabel 4.8 dibawah ini :

Tabel 3 Distribusi Frekuensi Responden Berdasarkan Pengetahuan Tentang Upaya Pencegahan Kanker Serviks di Puskesmas Putri Ayu Kota Jambi Tahun 2018

\begin{tabular}{ccc}
\hline Pengetahuan & Jumlah & \% \\
\hline Rendah & 18 & 40.0 \\
Tinggi & 27 & 60.0 \\
Jumlah & 45 & 100 \\
\hline
\end{tabular}

Hasil penelitian tabel 3
terhadap 45 WUS, gambaran
pengetahuan tentang upaya pencegahan Kanker Serviks melalui Tes IVA di Puskesmas Putri Ayu Kota Jambi tahun 2018, sebanyak 27 WUS $(60 \%)$ memiliki pengetahuan tinggi. Pengetahuan merupakan hasil tahu, dan ini terjadi setelah orang melakukan penginderaan terhadap suatu obyek tertentu. Penginderaan terjadi melalui panca indra manusia, yakni indra penglihatan, pendengaran, penciuman, rasa dan raba. Sebagian pengetahuan manusia diperoleh melalui mata dan telinga, (Notoadmodjo, 2012). Pengetahuan rendah disebabkan kurangnya informasi yang diterima oleh seseorang terhadap sesuatu sehingga menyebabkan kurangnya informasi yang dimiliki.

Menurut hasil penelitian Titik (2015) bahwa wanita usia subur yang memiliki pengetahuan rendah sebanyak 37 orang $(75 \%)$, wanita usia subur yang memiliki pengetahuan tinggi sebanyak 27 orang $(25 \%)$. Dapat disimpulkan bahwa secara umum pengetahuan wanita usia subur di Desa Ngino sebagian besar adalah rendah.

Penelitian di atas tidak sejalan dengan hasil penelitian yang dilakukan oleh Azmanaili (2014) tentang Hubungan antara FaktorFaktor yang Mempengaruhi dengan Masalah Upaya Pencegahan Kanker Serviks di Puskesmas Perawatan Jakarta Timur Tahun 2014 didapatkan bahwa sebagian besar responden 32 (75\%) memiliki faktor pengetahuan tentang upaya pencegahan kanker serviks rendah pada wanita usia subur. Hal ini perlu adanya peningkatan informasi masalah upaya pencegahan kanker serviks yang tinggi terhadap masalah pemahaman pasien dengan upaya pencegahan kanker serviks ke pelayanan kesehatan terdekat yang ada pada kondisi yang dialaminya sekarang untuk mencegah dari berbagai masalah kesehatan yang dialami oleh pasien saat adanya keluhan yang memperberat kondisi pasien saat sekarang.

Dari hasil penelitian dapat dilihat bahwa responden masih memiliki poengetahuan rendah tentang upaya pencegahan kanker serviks $(40 \%)$. Hal ini perlunya dilakukan pembinaan dalam bentuk pemberian informasi kesehatan yang 
baik terhadap pencegahan masalah kanker serviks dengan melakukan pemeriksaan ke pelayanan kesehatan terdekat dimana tujuanya menurunkan angka kejadian masalah kanker serviks yang terjadi pada wanita usia subur. Hasil penelitian ini sesuai dengan penelitian yang telah dilakukan oleh Astrid (2013) yang menyatakan bahwa ada hubungan pengetahuan dan dukungan keluarga tentang upaya pencegahan kanker serviks. Dengan nilai $p$-value $=0.020$ ( $p$-value $<$ 0.05). Kondisi untuk mengatasi masalah pengetahuan rendah dengan upaya pencegahan kanker serviks adalah dengan menganjurkan penderita kanker serviks untuk melakukan pemeriksaan kesehatan dipelayanan kesehatan terdekat seperti Puskesmas maupun Rumah Sakit terdekat.

Dari uraian di atas menggambarkan pemahaman wanita usia subur tentang kanker serviks sebagian besar rendah, kondisi ini sesuai dengan hasil yang ditemukan. Pengetahuan seseorang diperoleh dari aktivitas sendiri oleh individu seperti melihat, mendengar, merasakan bahkan mencoba sendiri sehingga individu tersebut memperoleh pengalaman nyata dan diperoleh pengalaman baru yang berupa pengetahuan. Pengetahuan yang baik dapat menstimulasi seorang untuk mengaplikasikannya dalam kehidupan sehari-hari, sehingga semakin banyak pengetahuan yang dimiliki dan semakin baik pula perilaku dan sikapnya, terutama dalam hal yang berhubungan dengan kesehatan. Dari pengalaman dan pembelajaran yang dimiliki wanita usia subur akan memperoleh pengetahuan yang baik, maka perlu ditingkatkan lagi bagi Puskesmas atau pelayanan kesehatan untuk melakukan promosi kesehatan khususnya tentang kanker serviks baik secara langsung maupun tidak lansung menggunakan media leaflet atau brosur.

\section{b. Sikap tentang Upaya Pencegahan Kanker Serviks}

Untuk melihat gambaran Sikap tentang Upaya Pencegahan Kanker Serviks di Puskesmas Putri Ayu Kota Jambi Tahun 2018, ada beberapa item pertanyaan yang diambil dari konsep pencegahan kanker serviks seperti menghindari faktor resiko kanker serviks, pola hidup sehat, melakukan vaksinasi HPV, dan melakukan deteksi dini dengan IVA. Untuk mengetahui secara rinci item yang dibahas dan hasil secara keseluruhan jawaban WUS dapat diketahui sebagai berikut: Berdasarkan distribusi jawaban WUS berdasarkan item pertanyaan Sikap tentang Upaya Pencegahan Kanker Serviks di Puskesmas Putri Ayu Kota Jambi Tahun 2018. WUS banyak yang setuju dengan pernyataan bahwa wanita yang belum menikah namun sudah melakukan hubungan seksual sangat beresiko terserang kanker serviks yaitu $23(51,1 \%)$ WUS. Kemudian WUS banyak yang setuju tentang pernyataan Wanita yang belum menikah tidak dianjurkan melakukan tes IVA yaitu 24 WUS $(53,3 \%)$, sementara wanita yang aktif secara seksual dianjurkan melakukan deteksi dini kanker serviks dengan tes IVA sebaiknya dilaksanakan setiap tahun walaupun statusnya belum menikah.. 
Sedangkan sebanyak $13 \quad(28,9 \%)$ WUS menjawab tidak setuju untuk pernyataan apabila terdapat gejala keputihan yang abnormal, perdarahan setelah senggama di curigai kanker serviks. Berdasarkan hasil distribusi frekuensi berdasarkan sikap dengan upaya pencegahan kanker serviks terdapat 2 kategori yaitu negatif dan positif. Untuk lebih jelasnya dapat dilihat berdasarkan tabel 4 dibawah ini :

\section{Tabel 4 Distribusi Frekuensi Responden Berdasarkan Sikap tentang Upaya Pencegahan Kanker Serviks di Puskesmas Putri Ayu Kota Jambi Tahun 2018}

\begin{tabular}{cccc}
\hline No & Sikap & Jumlah & \% \\
\hline 1 & Negatif & 21 & 46,7 \\
2 & Positif & 24 & 53,3 \\
Jumlah & 50 & 100 \\
\hline
\end{tabular}

Dari tabel 4 didapatkan bahwa WUS di Puskesmas putri Ayu memiliki sikap postif tentang upaya pencegahan kanker serviks sebanyak 24 responden $(53,3 \%)$. Sikap adalah reaksi atau respon seseorang yang masih tertutup. Terbentuknya sikap positif atau negatif seseorang terhadap suatu tindakan ditentukan dari seberapa jauh pemahaman seseorang terhadap objek yang diketahuinya.

Penelitian diatas sejalan dengan hasil penelitian yang dilakukan oleh Indah (2014) tentang Hubungan antara Sikap dengan Upaya Pencegahan Kanker Serviks di Puskesmas Perawatan Kota Bogor Tahun 2014 didapatkan bahwa sebagian besar responden $54(69,5 \%)$ memiliki sikap negatif terhadap masalah upaya pencegahan masalah kanker serviks. Hal ini perlu adanya peningkatan pemahaman tentang pencegahan kanker serviks dengan cara melakukan kunjungan kepuskesmas, sering berkonsultasi tentang kondisi penyakit yang dialami oleh pasien terutama yang berhubungan dengan reproduksi. Menurut asumsi peneliti terjadinya masalah sikap negatif dengan upaya pencegahan kanker serviks adalah kurangnya pemahaman tentang kanker serviks yang terjadi pada wanita usia subur. Untuk mengatasi masalah sikap negatif pada WUS tentang upaya pencegahan kanker serviks maka petugas kesehatan harus melakukan suatu kegiatan berupa penyuluhan kesehatan dan bekerjasama dengan perangkat desa, kader dan pustu di wilayah kerja Puskesmas. Dengan adanya penyuluhan kesehatan diharapkan WUS mengerti tentang kanker serviks dan upaya pencegahannya sehingga dapat terbentuk suatu sikap yang baik berupa sikap positif terhadap pencegahan kanker serviks dan mau melakukan pemeriksaan seperti melaksanakan tes IVA.

\section{SIMPULAN}

Setelah dilakukan penelitian diketahui bahwa Lebih dari setengah responden 24 responden $(53,3 \%)$ memiliki upaya pencegahan baik., Sebagian besar responden 27 responden $(60 \%)$ memiliki pengetahuan tinggi dan 21 responden ( 46,7\%) memiliki sikap positif.

\section{SARAN}

Peneliti berharp semoga masyarakat khususnya WUS dapat 
meningkatkan perilaku pencegahan kanker serviks dengan mencari informasi terutama di pelayanan kesehatan terdekat dan mau melaksanakan pemeriksaan Tes IVA khususnya.

Untuk peneliti selanjutnya penelitian ini dapat dijadikan sebagai bahan informasi dan acuan untuk melakukan penelitian tentang kanker serviks dengan variabel yang berbeda.

\section{DAFTAR PUSTAKA}

1. Afianty, $Y$ dan Anggi pratiwi. (2016). Seksualitas dan Kesehatan Reproduksi Perempuan. Jakarta: Raja Grafindo Persada

2. Andrijono. (2009). Kanker Serviks. Divisi Departemen Onkologi Obstetri Fakultas Kedokteran Universitas Indonesia. Jakarta

3. Arum, Puspita S. (2015). Stop Kanker Serviks. Yogyakarta: Suku Buku

4. Aspiani, Reni Y (2017). Asuhan Keperawatan Maternitas.Jakarta : Trans Info Media

5. Buletin Jendela Data dan informasi kesehatan semester 12015 Provinsi Jambi

6. Departemen Kesehatan Republik Indonesia. Undangundang Nomor 23 tahun 1992 tentang kesehatan (Diakses tanggal 15 November 2012)

7. Dianda. (2008). Mengenal Seluk Beluk Kanker. Katahati: Yogyakarta.

8. Dinas Kesehatan Kota Jambi. (2016). Data Deteksi Dini Kanker5 Serviks dengan
IVA Tes di seluruh Puskesmas Kota Jambi tahun 2016

9. Grepi, dkk (2013) dalam Afianty, Y dan Anggi pratiwi (2016). Seksualitas dan Kesehatan Reproduksi Perempuan.Jakarta: Raja Grafindo Persada

10. Hartono. (2015). Analisi Item Intrumen. Riau: Zanafa

11. Kemenkes. (2014). Hilangkan Mitos Tentang Kanker. dari http://www.depkes.go.id (Diakses 29 Desember 2014)

12. Klinik PKBI dara Jingga. (2016). Data Rekapitulasi tindakan pap smear di PKBI Klinik Dara Jingga Kota Jambi

13. L. Green (1980) dalam Notoatmodjo. (2010). Promosi Kesehatan Kebidanan. Jakarta: Rineka Cipta

14. Lestari, T (2015). Kumpulan Teori Untuk Kajian Pustaka Penelitian Kesehatan. Jakarta: Nuha Medika

15. Maliono. (2007) dalam Lestari, T (2015). Kumpulan Teori Untuk Kajian Pustaka Penelitian Kesehatan. Jakarta: Nuha Medika

16. Martini, N. K. (2013). Hubungan Karakteristik, Pengetahuan, dan Sikap Wanita Pasangan Usia Subur dengan Tindakan Pemeriksaan Pap Smear di Puskesmas Sukawati II. Karya Tulis Ilmiah, 22

17. Mustika. (2016). Hubungan pengetahuan dan sikap wus dengan Perilaku melakukan 
pemeriksaan iva di Kelurahan kotabaru wilayah kerja Puskesmas gondo kusuman II Yogyakarta

18. Novia. (2014). Hubungan antara pengetahuan wanita usia subur (wus) Tentang kanker serviks dan deteksi dininya dengan perilaku pemeriksaan dengan asam asetat(iva) di desa sikunir Wilayah kerja puskesmas gunung pati

19. Pusat Data dan Informasi.Infodatin-

Kanker.Jakarta: Kementerian Kesehatan RI. 2015

20. Puskesmas Putri. (2017). Jumlah Wanita Usia Subur yang berkunjung ke poli Imunisasi dan $\mathrm{KB}$ di Puskesmas Putri Ayu tahun 2016 dan 2017(Januar-Mei)

21. Rama(2009) dalam Aspiani, Reni Y (2017). Asuhan Keperawatan

Maternitas.Jakarta : Trans Info Media

22. Rasjidi (2011) dalam Aspiani, Reni Y (2017). Asuhan Keperawatan

Maternitas.Jakarta : Trans Info Media

23. Samadi,P. (2010). Yes,I Know Everything About Kanker Serviks!. Jakarta: Tiga Kelana

24. Savitri, Astrid. (2015). Kupas Tuntas Kanker Payudara, Leher Rahim, dan rahim. Jakarta: Pusat Baru Press

25. Siswanto, dkk .(2013). Metodologi Penelitian Kesehatan Dan Kedokteran. Yogyakarta: Bursa Ilmu
26. Soekanto (2002) dalam Lestari, T (2015). Kumpulan Teori Untuk Kajian Pustaka Penelitian Kesehatan. Jakarta: Nuha Medika

27. Sofiana Nurchayati (2014) Faktor-Faktor Yang Berhubungan Dengan Perilaku Pencegahan Kanker Serviks Pada Wanita Usia Subur

28. Suprayanto.(2011). Wanita Usia Subur (WUS) http: //id.wikipedia.org/wiki/promo si kesehatan, diakses tanggal 15 November 2012

29. Suyanto. (2016) Hubungan Pengetahuan Dan Sikap Terhadap Tindakan Wanita Pekerja Seksual Tidak Langsung Tentang Pap Smear Dan Inspeksi Visual Asetat sebagai Deteksi Dini Kanker Serviks Di Hotspot X Kecamatan Lima Puluh Pekanbaru

30. Wawan dan Dewi. (2010). Teori dan Pengukuran Pengetahuan, Sikap dan. Perilaku Manusia Yogyakarta : Nuha Medika.

31. WHO (2006) dalam Afiyanti dan Anggi (2016).Seksualitas dan Kesehatan Reproduksi Perempuan. Jakarta: Raja Grafindo Persada

32. WHO (2014). Comprehensive Cervical Center Control.

33.Yuliatin, S. (2010). Cegah dan Tangkal Ca Serviks. Surabaya: Java Pustaka Group. 